Article

\title{
Intraspecific Fine-Root Trait-Environment Relationships across Interior Douglas-Fir Forests of Western Canada
}

\author{
Camille E. Defrenne ${ }^{1, *}$, M. Luke McCormack ${ }^{2}$, W. Jean Roach ${ }^{3}$, Shalom D. Addo-Danso ${ }^{4}$ and \\ Suzanne W. Simard ${ }^{1}$ \\ 1 Department of Forest and Conservation Sciences, Faculty of Forestry, University of British Columbia, \\ Vancouver, BC V6T 1Z4, Canada \\ 2 Center for Tree Science, The Morton Arboretum, Lisle, IL 60532, USA \\ 3 Skyline Forestry Consultants Ltd., Kamloops, BC V2C 1A2, Canada \\ 4 CSIR-Forestry Research Institute of Ghana, KNUST, P. O. Box 63, Kumasi, Ghana \\ * Correspondence: camille.defrenne@ubc.ca; Tel.: +33-6-44-89-61-63
}

Received: 3 June 2019; Accepted: 28 June 2019; Published: 30 June 2019

\begin{abstract}
Variation in resource acquisition strategies enables plants to adapt to different environments and may partly determine their responses to climate change. However, little is known about how belowground plant traits vary across climate and soil gradients. Focusing on interior Douglas-fir (Pseudotsuga menziesii var. glauca) in western Canada, we tested whether fine-root traits relate to the environment at the intraspecific level. We quantified the variation in commonly measured functional root traits (morphological, chemical, and architectural traits) among the first three fine-root orders (i.e., absorptive fine roots) and across biogeographic gradients in climate and soil factors. Moderate but consistent trait-environment linkages occurred across populations of Douglas-fir, despite high levels of within-site variation. Shifts in morphological traits across regions were decoupled from those in chemical traits. Fine roots in colder/drier climates were characterized by a lower tissue density, higher specific area, larger diameter, and lower carbon-to-nitrogen ratio than those in warmer/wetter climates. Our results showed that Douglas-fir fine roots do not rely on adjustments in architectural traits to adapt rooting strategies in different environments. Intraspecific fine-root adjustments at the regional scale do not fit along a single axis of root economic strategy and are concordant with an increase in root acquisitive potential in colder/drier environments.
\end{abstract}

Keywords: belowground; biogeographic gradient; Douglas-fir; fine root; mycorrhizal fungi; plant traits; root diameter; root economics; root tissue density

\section{Introduction}

Functional traits of fine roots and mycorrhizal symbionts have become central to understanding belowground acquisition strategies and plant responses to environmental change from local to global scales [1-5]. Recent syntheses of large-scale datasets have facilitated exploration of interspecific (i.e., among-species) fine-root functional trait variation. These studies have notably advanced our understanding of the fundamental constraints underlying fine-root trait variation (e.g., phylogeny and climate and growth form [4,6-9]). Importantly, studies across plant species have reported inconsistent evidence for a single root economic spectrum varying from more conservative roots with high structural investment to more cheaply constructed, acquisitive root types [5,10-12]. As a result, a multidimensional root trait framework has begun to emerge [13-17].

Thus far, most studies have focused on assessing fine-root functional trait variation among species, following the assumption that among species differences in root trait values are greater than those 
within species, as found in studies of aboveground traits [18-20]. However, within-species variation in fine-root functional traits can also be important, reflecting both heritable genetic variation [21,22] and phenotypic plasticity $[3,7,23]$. Intraspecific variation in fine-root trait expression is, therefore, likely to be an important driver of plant community assembly and may enable populations of plants to adjust to environmental conditions and changing climate $[7,21]$. Despite recent studies stressing the need for empirical research that links intraspecific plant trait variation to the environment $[20,24,25]$, such investigations with respect to fine roots have only been conducted on relatively few species and in limited environmental contexts [3,21,22]. For instance, Zadworny et al. [21,22] found that fine-root traits of Scots pine (Pinus sylvestris) were related to mean annual temperature (MAT) as roots were thicker with lower specific root length (SRL) and lower root tissue density (RTD) in colder environments. The larger diameters were associated with a greater cortex area, which may indicate an overall shift among Scot pine trees from northern populations to adapt to cold environments by building cheaper fine roots (low RTD), with potentially higher absorptive capacity. Alternatively, across a similar temperate to boreal transect, Ostonen et al. [3] showed that Norway spruce (Picea abies) and Scots pine trees, at higher latitudes, had longer and thinner fine roots with higher RTD, compared to trees in warmer, lower latitude forests. According to Ostonen et al. [3], these adjustments were also closely related to an overall increase in absorptive root biomass. Despite some similarities, notable contradictions in the aforementioned studies demonstrate the need to better understand intraspecific belowground trait-environment linkages [1,2,6].

To test whether fine-root functional traits relate to the environment at the intraspecific level, we quantified root trait variation in interior Douglas-fir (Pseudotsuga menziesii var. glauca (Beissn). Franco; hereafter Douglas-fir) across a biogeographic gradient, in western Canada. In a previous study across the same gradient, we focused on variation in the ectomycorrhizal fungal species community and functional traits [26]. We notably found that fungi with rhizomorphs (e.g., Piloderma sp.) or proteolytic abilities (e.g., Cortinarius sp.) dominated communities in the warmer and less fertile environments of the gradient. Conversely, Ascomycetes (e.g., Cenococcum geophilum) or fungi that explore short distances in the soil were favored the in colder/drier environments where soils were richer in total nitrogen $(\mathrm{N})$. This previous study was notably inconclusive regarding the potential link between root and fungal acquisition strategies at the regional scale.

In the present study, we measured aspects of root morphology including fine-root diameter, RTD, SRL and specific root area (SRA). We also assessed fine-root chemical (root $\mathrm{N}$ concentration and root carbon-to-nitrogen ratio, $\mathrm{C}: \mathrm{N}$ ) and architectural (branching intensity and dichotomous branching index, DBI) traits. We first hypothesized that MAT would be an important driver of root trait variation such that trade-offs among traits would favor greater root acquisitive capacity in colder climates in order to compensate for more limited resource availability and a shorter window for growth and acquisition. These trade-offs should translate into a higher SRL and SRA and lower root diameter, RTD, and root $\mathrm{C}: \mathrm{N}$ because such fine roots are cheaply-constructed and are assumed to be more acquisitive, whereas thicker fine roots with a higher construction cost are hypothesized to be more conservative [13]. Increased root branching intensity, particularly within resource patches, is generally associated with greater root metabolism and enhanced root proliferation as it results in a higher density of more metabolically active, and more absorptive, first- and second-order roots [21,27,28]. Therefore, we also expected higher root branching intensity in colder/drier environments. We explored pairwise trait relationships to assess whether trait trade-offs, at the intraspecific level, are consistent with an acquisitive-conservative trait spectrum. We also partitioned variation in fine-root traits at different ecological scales, starting with the regional scale and then to the site, tree, and individual root branch levels, and tested a second hypothesis that the majority of the variation in fine-root traits of Douglas-fir would occur at the regional scale, consistent with aboveground traits [29]. 


\section{Results}

\subsection{Fine-root Trait Response to Abiotic Factors}

Responses of fine-root traits to abiotic factors were mixed and these factors only explained around $10 \%$ of the variation in fine-root traits, as most of the variation occurred at small ecological scales (e.g., root branch, individual soil block; Figure 1). With the exception of SRL, most traits were responsive to at least one abiotic factor, yet the direction and strength of these responses were often dependent on root order (Figure 2; Table 1 and Table S1). Root diameter, SRA, and RTD each responded significantly to different aspects of climate. However, the size of the effect of environmental factors was relatively small (Figure 2), and the proportion of the variance explained by the different climatic factors was low (all marginal $\mathrm{R}^{2}<0.1$; Table 1 ). Still, most first- and second-order root morphological traits were significantly related to MAT, with root diameter and RTD increasing with MAT, while SRA decreased with MAT $(p<0.05)$. In contrast, to first- and second-order roots, the diameter of third-order roots decreased with mean annual precipitation (MAP) as well as cation exchange capacity (CEC), while SRA of third-order roots increased with soil available P. Root tissue density of third-order roots was unrelated to any abiotic factor (Figure 2). The C:N ratios of first- and third-order roots were most responsive to soil properties, with $\mathrm{C}: \mathrm{N}$ of first- and third-order roots being positively related to soil $\mathrm{C}: \mathrm{N}$. The C:N ratio of third-order roots was also positively related to MAT, but it was negatively related to CEC and soil available P (Figure 2; Table 1). The positive relationship between branching intensity and soil available $\mathrm{P}$ was only marginally significant (marginal $\mathrm{R}^{2}=0.02, p=0.05$; Table 1 ), while DBI (values range from 0 , a fully dichotomous branching pattern to 1 , a fully herringbone branching pattern [30,31]) was not related to any of the environmental factors considered in this study.
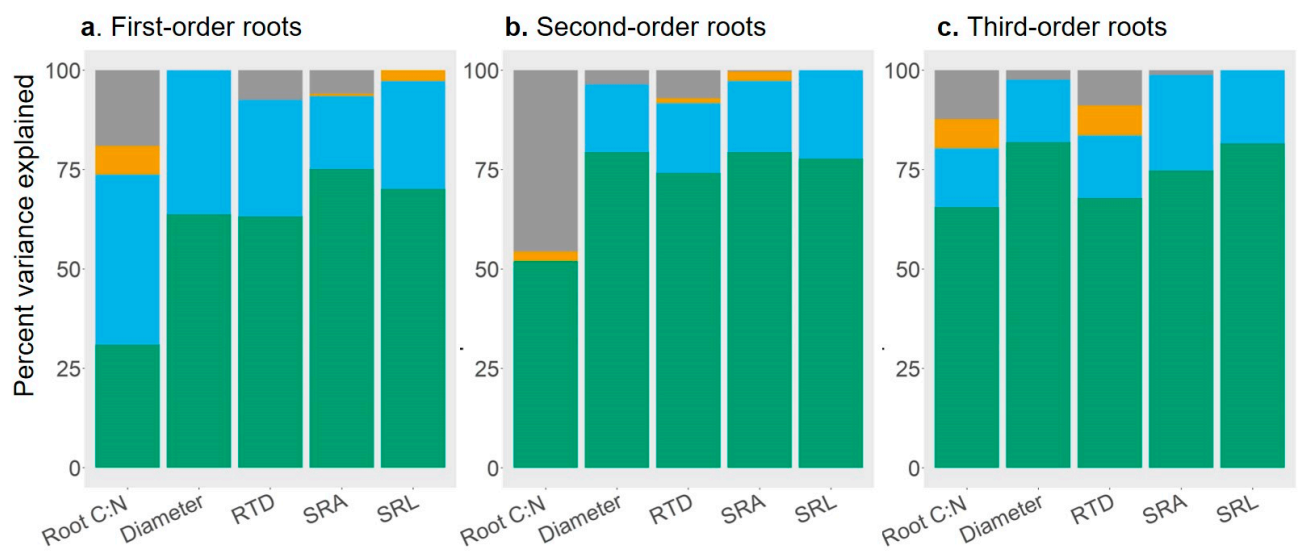

Fine-root trait of interior Douglas-fir

$$
\text { Region Site Soil block } \square \text { Fine-root branch }
$$

Figure 1. Variance partitioning of functional traits of the first three fine-root orders of interior Douglas-fir at different hierarchically structured ecological scales (region, site, soil block and fine-root branch). Root C:N, root carbon-to-nitrogen ratio; Diameter $(\mathrm{mm})$; RTD, root tissue density $\left(\mathrm{mg} \mathrm{cm}^{-3}\right)$; SRA, specific root area $\left(\mathrm{cm}^{2} \mathrm{~g}^{-1}\right)$; SRL, specific root length $\left(\mathrm{m} \mathrm{g}^{-1}\right)$. 

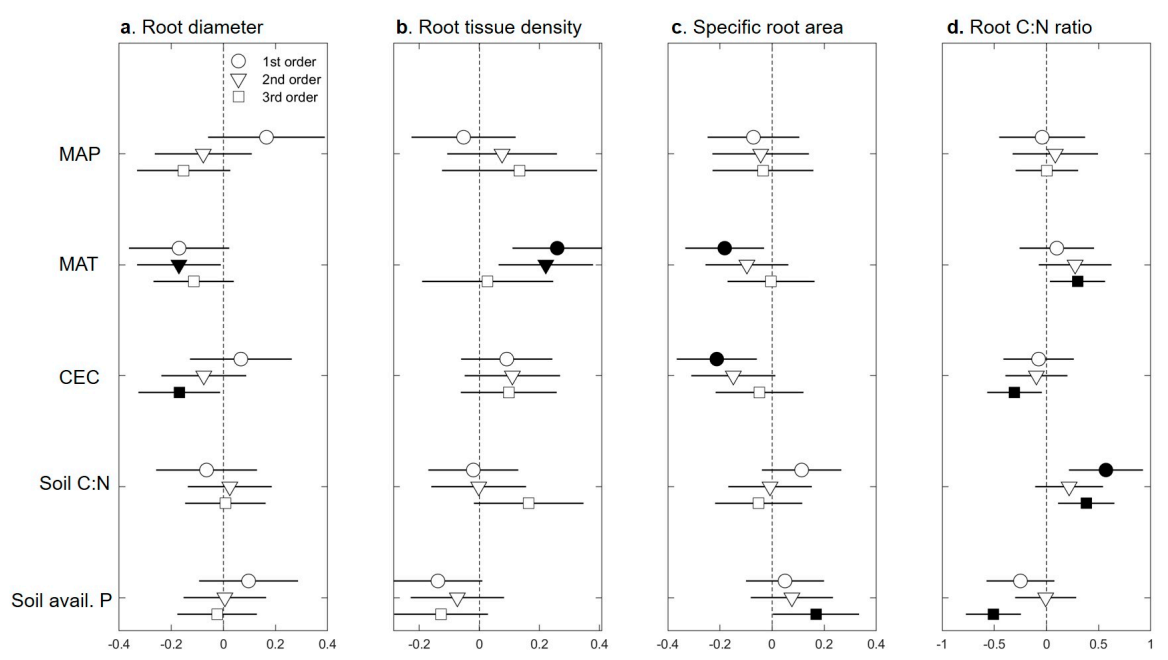

Standardized beta coefficient of linear mixed effect model

Figure 2. Effects of environmental variables (on the left of the figure) on interior Douglas-fir fine-root morphological (a-c) and chemical (d) traits. Standardized beta coefficients of linear mixed models (See Table 1) illustrate the effect of each environmental factor on a given fine-root trait in terms of its standardized effect size. MAP, mean annual precipitation (mm); MAT, mean annual temperature $\left({ }^{\circ} \mathrm{C}\right)$; CEC, cation exchange capacity $\left(\mathrm{cmol}(+) \mathrm{kg}^{-1}\right)$; soil C:N, soil carbon-to-nitrogen ratio; soil avail. $\mathrm{P}$, soil available phosphorus (ppm). Circles indicate average estimates and lines indicate $95 \%$ confidence intervals. Filled circles indicate a significant effect $(p<0.05)$ of a given environmental variable on a trait. 
Table 1. Effect of climate (1980-2010) and soil variables on fine-root morphological, chemical, and architectural traits of interior Douglas-fir. Linear mixed-effects models were fitted with a restricted maximum likelihood. Model significance was tested with a log likelihood ratio test and significance of the fixed predictor(s) was tested with a type II Wald $\chi^{2}$ test. The specific root length and Dichotomous branching index were not included in the table because they were not related to any of the environmental factors considered in this study.

\begin{tabular}{|c|c|c|c|c|c|c|c|c|c|c|c|}
\hline \multirow{2}{*}{\multicolumn{2}{|c|}{ Data Trans. }} & \multirow{2}{*}{$\operatorname{LR}^{1} \chi^{2}$} & \multirow{2}{*}{ LR d.f. } & \multirow{2}{*}{$p$-Value } & \multicolumn{2}{|c|}{ Model Fit } & \multirow{2}{*}{ Predictor } & \multirow{2}{*}{ Estimate } & \multirow{2}{*}{$\begin{array}{l}\text { Standard } \\
\text { Error }\end{array}$} & \multirow{2}{*}{ Wald $\chi^{2}$} & \multirow{2}{*}{$p$-Value } \\
\hline & & & & & Marginal $\mathbf{R}^{2}$ & Conditional $\mathbf{R}^{2}$ & & & & & \\
\hline \multicolumn{12}{|c|}{ Root diameter } \\
\hline 1 st & NA & & & & & & & & & & \\
\hline 2nd & $\log _{10}$ & 5.43 & 1 & 0.02 & 0.03 & 0.19 & MAT $^{2}$ & -0.01045 & 0.00397 & 7.16 & 0.01 \\
\hline \multirow[t]{2}{*}{$3 \mathrm{rd}$} & $\log _{10}$ & 7.50 & 2 & 0.02 & 0.03 & 0.18 & $\mathrm{MAP}^{3}$ & -0.00007 & 0.00003 & 6.82 & 0.01 \\
\hline & & & & & & & $\mathrm{CEC}^{4}$ & -0.00173 & 0.00076 & 5.19 & 0.02 \\
\hline \multicolumn{12}{|c|}{ Specific root area } \\
\hline \multirow[t]{2}{*}{1 st } & $\log _{10}$ & 9.03 & 2 & 0.01 & 0.05 & 0.19 & MAT & -0.00857 & 0.00572 & 5.56 & 0.02 \\
\hline & & & & & & & CEC & -0.00177 & 0.00059 & 7.33 & $<0.01$ \\
\hline 2nd & $\log _{10}$ & 3.83 & 1 & 0.05 & 0.02 & 0.18 & CEC & -0.00114 & 0.00056 & 4.10 & 0.04 \\
\hline $3 r d$ & $\log _{10}$ & 4.81 & 1 & 0.03 & 0.02 & 0.22 & Soil avail. $\mathrm{P}^{5}$ & 0.00029 & 0.00006 & 5.03 & 0.02 \\
\hline \multicolumn{12}{|c|}{ Root tissue density } \\
\hline \multirow[t]{2}{*}{ 1st } & $\log _{10}$ & 8.34 & 2 & 0.01 & 0.05 & 0.34 & MAT & 0.01826 & 0.00629 & 8.44 & $<0.01$ \\
\hline & & & & & & & Soil avail. P & -0.00010 & 0.00005 & 3.98 & 0.04 \\
\hline 2nd & $\log _{10}$ & 5.61 & 1 & 0.02 & 0.04 & 0.20 & MAT & 0.01464 & 0.00560 & 6.82 & $<0.01$ \\
\hline $3 \mathrm{rd}$ & NA & & & & & & & & & & \\
\hline \multicolumn{12}{|c|}{ Root C:N } \\
\hline \multirow{6}{*}{$\begin{array}{c}\text { 1st } \\
\text { 2nd } \\
\text { 3rd (multiple } \\
\text { linear regression) }\end{array}$} & $\log _{10}$ & 9.19 & 1 & $<0.01$ & 0.28 & 0.60 & Soil C:N ${ }^{6}$ & 0.00854 & 0.00236 & 13.12 & $<0.01$ \\
\hline & NA & & & & & & & & & & \\
\hline & $\log _{10}$ & F-value $=7.17$ & 4 & $<0.01$ & $\begin{array}{l}\text { Multiple } R^{2} \\
\quad=0.35\end{array}$ & $\begin{array}{c}\text { Adjusted } R^{2}= \\
0.30\end{array}$ & MAT & 0.02098 & 0.00965 & 4.72 & 0.03 \\
\hline & & & & & & & CEC & -0.00218 & 0.00087 & 6.3 & 0.02 \\
\hline & & & & & & & Soil C:N & 0.00538 & 0.00173 & 9.66 & $<0.01$ \\
\hline & & & & & & & Soil avail. $\mathrm{P}$ & -0.00028 & 0.00008 & 13.2 & $<0.01$ \\
\hline $\begin{array}{l}\text { Root branching } \\
\text { intensity }\end{array}$ & $\log _{10}$ & 3.97 & 1 & 0.05 & 0.02 & 0.18 & Soil avail. P & 0.00027 & 0.00013 & 4.07 & 0.04 \\
\hline
\end{tabular}

Values in bold indicate statistically significant results at $p<0.05$. data trans., data transformation; NA, not applicable. ${ }^{1}$ LR, log likelihood ratio. ${ }^{2} \mathrm{MAT}$, mean annual temperature $\left({ }^{\circ} \mathrm{C}\right)$. ${ }^{3} \mathrm{MAP}$, mean annual precipitation (mm). ${ }^{4} \mathrm{CEC}$, effective cation exchange capacity $\left(\mathrm{cmol}(+) \mathrm{kg}^{-1}\right) .{ }^{5}$ Soil avail. $\mathrm{P}$, soil available phosphorus $\left(\mathrm{PO}_{4}-\mathrm{P}\right.$; orthophosphate as phosphorus; $\left.\mathrm{ppm}\right)$.

${ }^{6}$ Soil C:N, soil carbon-to-nitrogen ratio. 


\subsection{Ordination and Trait Correlation}

Consistent among the three root orders, root trait variation did not fit into one dimension of the ordination (Figures 3 and S1). Root morphological traits (SRL, SRA, diameter, and, to a lesser extent, RTD), were well correlated with the first dimension, which explained c. $30 \%$ of the variation for the three root orders and represented a gradient from thinner, high SRL roots to thicker, low SRL roots. This gradient was present within regions, as the five regions considered were not well separated along the first axis. The second axis of variation accounted for c. $22 \%$ of the total variation and was best represented by chemical traits (root $\mathrm{C}$ and $\mathrm{N}$; $\operatorname{root} \mathrm{C}: \mathrm{N}$ was not included to avoid redundancy). Regions were well separated across this axis, which represented a gradient of higher root $\mathrm{N}$ (Kamloops, Revelstoke) to lower root N (Nelson, Williams Lake). Root architectural traits were not well represented along any of the axes (scores $<0.15$, for each root order) nor were they well captured by the third PC axis which accounted for $<20 \%$ of the variation in each root order Figures 3 and S1).

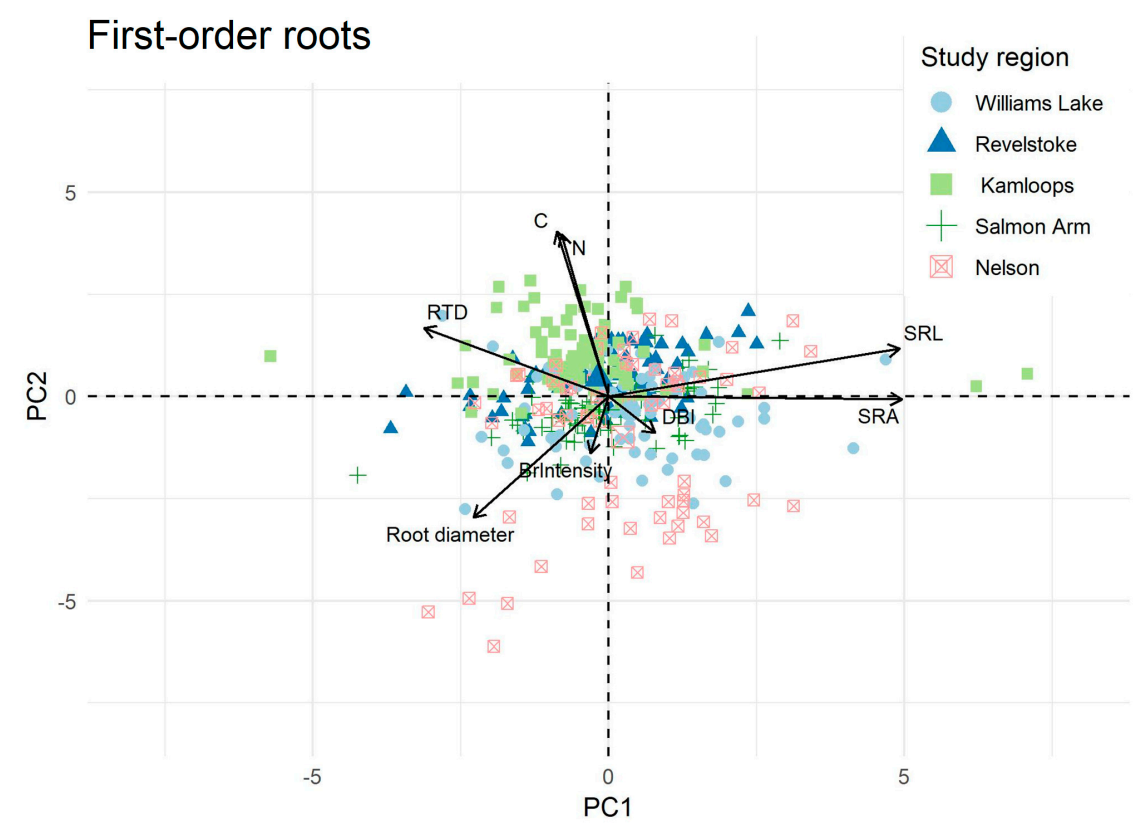

Figure 3. Ordination plot of study regions (five in total) across a biogeographic gradient based on principal component analysis of interior Douglas-fir first-order root traits. C, root carbon concentration (\%); N, root nitrogen concentration (\%); SRA, specific root area $\left(\mathrm{cm}^{2} \mathrm{~g}^{-1}\right)$; SRL, specific root length $\left(\mathrm{mg}^{-1}\right)$; RTD, root tissue density $\left(\mathrm{mgcm}^{-3}\right)$; BrIntensity, branching intensity (the number of first- order root/length of second- order root; $\mathrm{cm}^{-1}$ ); DBI, dichotomous branching index, values closer to 0 indicate a dichotomous branching pattern and values closer to 1, a herringbone branching pattern, see [31]. PC, principal component, PC1 $=30 \%$; PC2 $=22 \%$, see Figure S1.

Consistent within each root order, the variation in RTD was negatively correlated with that of root diameter, which was weakly negatively correlated with the variation in SRL (Table S2). As expected from mathematical dependencies (i.e., the root volume and area depend on root diameter), variations in root diameter, SRA, and RTD were correlated. However, the variation in root C:N ratio was not correlated with the variation in morphological traits. Architectural traits were not correlated with any of the morphological traits.

\subsection{Partition of Fine-root Trait Variance}

More than half of the root morphological trait variance in Douglas-fir was expressed at small ecological scales (tree cluster and branch levels; Figure 1; Figure S2). In other words, differences among fine-root branches within individual soil blocks explained most of the variation in root diameter, RTD, SRL, and SRA. Consistent among morphological traits and root orders, the variation among 
soil blocks (within sites) accounted for, on average, $20 \%$ of the total variation. This pattern of high variance at small scales was even stronger for the architectural traits (branching intensity and DBI), which expressed over $90 \%$ of their variation among branches and tree cluster samplings (Figure S2). Alternatively, the proportion of the root trait variance at the cross-site level was negligible for root diameter, SRL and SRA (Figure 1). At the regional scale, intraspecific variation was the highest for root $\mathrm{C}: \mathrm{N}$ and RTD. On average for the three orders, the regional scale accounted for roughly a quarter and $8 \%$ of the total variation in root C:N and RTD, respectively.

\section{Discussion}

Moderate but consistent trait-environment linkages occurred across populations of Douglas-fir that were distributed across climatic and edaphic gradients in western Canada, despite high levels of within-site variation. Our first hypothesis was partly confirmed, as MAT was the environmental variable that was most highly correlated with fine-root morphological traits. However, fine-root $\mathrm{C}: \mathrm{N}$ was more responsive to soil properties (soil C:N, soil avail. P and CEC). Generally, fine roots in colder or drier climates were characterized by potentially higher acquisitive capacities (based on trade-offs among morphological and chemical traits), and variations in morphological and chemical traits represented two separate axes for fine-root adjustments. We rejected our second hypothesis as root trait variance was unevenly distributed across ecological scales, with over $50 \%$ of the variation in morphological traits occurring within individual soil blocks at a single site.

\subsection{Fine-root Functional Traits Relates to the Environment}

\subsubsection{Fine-root Morphology}

Across the biogeographic gradient, first- and second-order roots of Douglas-fir trees tended to increase in diameter and SRA but decreased in RTD with decreasing MAT. This result partly agrees with our first hypothesis because, with the exception of increasing root diameter, these trait adjustments are expected to increase root resource acquisition potential, which was expected under colder climatic conditions. The response of Douglas-fir morphological and chemical traits to MAT were largely consistent with that of Scots pine absorptive fine roots reported by Zadworny et al. [22]. However, these results are in opposition to those reported by Ostonen et al. [3], despite similar temperature ranges used in both previous studies. To adjust to colder conditions, fine roots may increase their potential for soil resource acquisition to compensate for a more limited resource availability and a shorter window for growth and acquisition [14-16,28,32]. Alternatively, trees in colder environments may build fine roots with higher tissue protection and persistence (e.g., an increased number of phellem layers, increased phenolic compound content [22]). Our results provide evidence that in environments where temperature limits the availability of soil resources, fine roots increase their potential to acquire resources via morphological adjustments manifesting as greater surface area of roots per unit biomass invested (i.e., higher SRA).

In contrast to increases in SRA and reduced RTD, the larger diameter roots observed at lower MAT are generally associated with a more resource-conservative strategy. Plants with a conservative strategy are frequently expected to have fine roots with low SRL, large diameter, high RTD, low N concentration, low uptake capacity, low respiration rate and a long life span [12]. However, large diameter roots could also be associated with increased associations with mycorrhizal fungi $[7,33]$. Therefore, the increase in Douglas-fir root diameter in our study may be associated with enhanced root absorptive capacity if it coincides with an increased association with mycorrhizal fungi or greater hyphal growth [34].

In our study system, we did not observe significant changes in the ectomycorrhizal colonization rate across the gradient, which averaged c. $95 \%$ for all the sites (data not shown), consistent with other studies in this region $[35,36]$. The constrained responses of the ectomycorrhizal colonization rate observed here may be because a Douglas-fir has relatively thick fine roots, which are generally associated with higher, and sometimes more constant, levels of fungal colonization [27,37,38]. However, 
a single measure of colonization rate may less relevant than ectomycorrhizal community composition in Douglas-fir forests [39] and may be more relevant in arbuscular mycorrhizal plant species [7,33]. In a complementary study across the same biogeographic gradient, we showed that root diameter was not related to patterns of ectomycorrhizal fungal exploration type (see [40]) and that fine roots with high RTD and low C:N were more frequently colonized by ectomycorrhizal fungi with short emanating hyphae [26]. Whether association with ectomycorrhizal fungi that proliferate short emanating hyphae could lead to increased acquisitive capacities of thick, large-diameter Douglas-fir fine roots requires further research. Additional assessments of the fungal hyphal production rate and densities in soils are also needed to better assess associations with, and potential reliance of, Douglas-fir trees on their ectomycorrhizal partners across environmental gradients [34]. Finally, we cannot exclude that the trade-offs observed among morphological traits may not necessarily stem from an optimization of resource acquisition by either Douglas-fir trees or ectomycorrhizal fungi. For example, interspecific competition with tree neighbors, which was not quantified in our study, could have affected the fine-root functional traits of Douglas-fir trees.

\subsubsection{Fine Root Chemistry and Architecture}

The fine-root $\mathrm{C}: \mathrm{N}$ ratio was most responsive to soil properties (soil C:N, soil available phosphorus and $\mathrm{CEC}$ ). Fine-root $\mathrm{N}$ concentration increased with increasing soil $\mathrm{pH}, \mathrm{CEC}$ and the decreasing soil $\mathrm{C}: \mathrm{N}$ ratio, which is potentially associated with greater nutrient uptake at the level of the individual fine root. The more fertile soils in our study area occurred in colder/drier regions and likely limited the diffusion rate of soil resources. Therefore, high root $\mathrm{N}$ concentrations with higher SRL, higher SRA, and lower RTD, which are generally associated with a shorter root lifespan and may represent a strategy to thrive where nutrient availability is heterogeneous and intermittent due to seasonality and soil freezing [4]. In the less fertile soils of our study area, the growth of Douglas-fir trees may not be limited by the low nutrient availability because of the high MAT and MAP. Accordingly, in these environments, we observed a more resource-conservative root strategy (higher RTD, C:N ratio and lower SRA). As suggested by Freschet et al. [6], in wetter environments with low nutrient availability, investments in higher branching intensity and/or mycorrhizal hyphae may be more beneficial to capture available $\mathrm{N}$ prior to leaching rather than investing in high metabolism (higher root $\mathrm{N}$ concentration).

Our results do not provide strong evidence that Douglas-fir fine roots rely heavily on adjustments in architectural traits. The relatively low values and narrow range of variation of root branching intensity are consistent with those of other ectomycorrhizal gymnosperm species considered by Tobner et al. [41] and Liese et al. [28]. These low values could be related to the consistently high rate of ectomycorrhizal colonization across our gradient, which suggests that local proliferation of fungal hyphae instead of increased fine-root branching may be the primary pathway to facilitate greater proliferation and exploitation of the soil environment.

\subsection{Intraspecific Root Trait Variation}

Contrary to our second hypothesis, the highest proportion of root trait variation was not at the regional scale. Though aspects of fine-root trait variation were significantly related to abiotic factors across regions, morphological, architectural, and, to a lesser extent, chemical traits, expressed the majority of their variation among root branches obtained from soil blocks within individual forest stands. Although our study was primarily designed to investigate fine-root trait-environment linkages at the regional scale, these findings demonstrate that processes at lower ecological scales are also important in determining root trait variation. It is not always feasible to intensively sample and quantify root trait variation at such small scales (i.e., within plot or even within tree/tree cluster variation), but in light of this result, care should be taken when interpreting and extrapolating a single mean value for a stand-level functional trait or for an individual species [42]. Thus, while environmental filters operate on the overall distribution of trait values within a region, their effects are lessened due to local variation among trees and root branches. 
The high variation in root traits observed among branches within a single sampling location could be explained by differences in resource allocation or by differences in ectomycorrhizal symbiont identity. This may, in turn, affect carbon allocation to each root branch and the distinct morphology and chemistry expressed by individual roots [2,40]. For instance, the concentration of primary photosynthates in ectomycorrhizal root tips, such as starch, glucose, and non-structural carbohydrates, can change substantially among ectomycorrhizal symbionts [43]. Similarly, Pickles et al. [44] demonstrated that the distribution of many ectomycorrhizal individuals is often patchy. This leads to the possibility that different soil blocks from within the same site may be dominated by morphologically distinct ectomycorrhizas, contributing to the high variation in root traits at small spatial scales.

While our study design did not allow testing the relative contributions of genotypic vs. environmental variation, other work focused on aboveground traits in Douglas-fir as well as in root traits of Scots pine both suggest a high degree of genetic control on plant functional traits $[21,45,46]$. In this case, individuals and local populations of Douglas-fir may be limited in their ability to adjust to local changes in climate through phenotypic plasticity as root traits would primarily be under genetic controls. However, the high degree of within site variation observed here also indicates substantial within population root trait variation, which may enable some acclimation.

\section{Conclusions}

Across regional gradients of climate and edaphic factors in western Canada, the majority of Douglas-fir fine-root trait variance occurred within sites. However, we also identified moderate but consistent trait-environment linkages across populations of Douglas-fir. Generally, colder/drier climates were characterized by fine roots with a lower RTD, higher SRA, higher diameter, and lower $\mathrm{C}: \mathrm{N}$ ratio. We also provided evidence for decoupled variations in fine-root morphological and chemical traits. These findings highlight the existence of multiple axes of within species fine-root adjustments that were consistent with increasing acquisitive potential of fine roots in harsher environments. The substantial within population root trait variation may then enable further acclimation at the stand level. As predicted changes in climate will likely impact belowground processes with important outcomes for tree persistence and resilience, further work connecting root traits and environmental variation will be particularly important to ensure that well-adapted tree populations are regenerated.

\section{Materials and Methods}

\subsection{Biogeographic Gradient}

A biogeographic gradient, including five study regions ranging in latitude from 49.6 to $51.7^{\circ} \mathrm{N}$, was located within the natural range of Douglas-fir in British Columbia (Figure 4). Two regions (Kamloops and Williams Lake) were in the Interior Douglas-fir biogeoclimatic zone (IDF) and three regions (Salmon Arm, Nelson, and Revelstoke) were in the Interior Cedar-Hemlock biogeoclimatic zone (ICH) [47]. Regions were distributed along substantial precipitation and temperature gradients (see Table 1 in [26]; Figure S3). Sites in Williams Lake had the lowest MAT (on average $3.4^{\circ} \mathrm{C}$ ) followed by Revelstoke, Kamloops, Salmon Arm and Nelson (on average $7.3^{\circ} \mathrm{C}$ ). The driest region was Kamloops (average MAP, $441 \mathrm{~mm}$ ), and the wettest region was Revelstoke (average MAP $1200 \mathrm{~mm}$ ). Unlike other large environmental gradients that often correspond to wide ranges in latitude and daylength (e.g., [3]), the limited latitudinal range encompassed here corresponds to minimal differences in day length among the study regions.

In each region, three replicated study sites separated by at least $400 \mathrm{~m}$ were selected in naturally regenerated, mature, closed-canopy forest stands on ecosystems that best reflect the regional climate (namely, zonal ecosystems [47]). The average stand age at each region ranged from 98 years old (Revelstoke) to 143 years old (Salmon Arm; Table S3). The northern-most stands in the IDF zone were growing on Luvisolic soils, and the southern-most stands in the ICH zone occurred predominantly on Brunisolic soils (Table S3; [48,49]). Soils in the southern-most regions (Nelson, Revelstoke and Salmon 
Arm) were N-limited, but the mineral soil available P concentration was up to five times greater than that in the northern regions. The mineral soils in Revelstoke and Nelson were also characterized by low CEC and low soil pH compared to those in the northern regions (see Table 1 in [26]). In the semi-arid regions of interior British Columbia, Douglas-fir occurs in pure stands (in the IDF), while in the wetter regions, Douglas-fir trees grow in mixed species forests (in the ICH; [44]). Consequently, six sites contained pure Douglas-fir forest stands, and nine sites had mixed stands (Table S3). The proportion of the Douglas-fir by basal area ranged from $49 \%$ in the mixed, evenly-aged forest stands of Salmon Arm to $100 \%$ in the pure, unevenly-aged forest stands of Kamloops (Table S3).

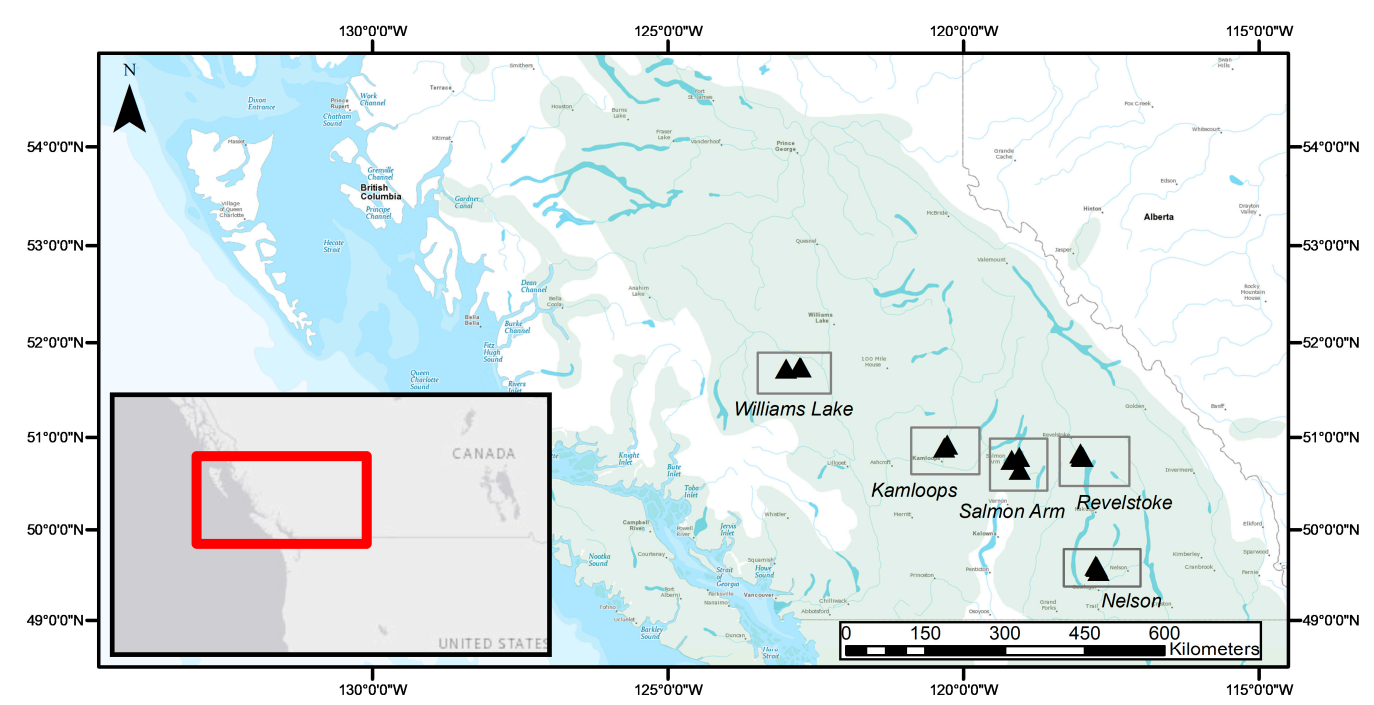

Figure 4. Geographical distribution of study regions (rectangles) and forest sites (3 triangles per study region) across the current natural range of interior Douglas-fir (Pseudotsuga menziesii var. glauca; green shading) in British Columbia, Canada. This figure was reproduced from [26].

\subsection{Fine-Root Sampling and Processing}

We used a nested strategy for sampling fine roots across ecological scales. A single sample plot of $30 \mathrm{~m} \times 30 \mathrm{~m}$ containing at least ten dominant or co-dominant Douglas-fir trees was established at each site in summer 2016. We selected five healthy Douglas-fir trees per plot in a manner to avoid clumping of the sampling location. For each selected tree, a coarse root originating from the target tree was identified and traced $200 \mathrm{~cm}$ out from the trunk. At that point, a single soil block $(20 \mathrm{~cm} \times 20 \mathrm{~cm} \times 20 \mathrm{~cm}$ ) was extracted as closely as possible to the coarse root. Soil samples were collected by hammering a steel frame into the soil and the block were extracted using a flat shovel. In addition, one organic (L, F, and $\mathrm{H}$ layers) and one mineral soil (upper mineral horizons $\mathrm{A}$ and $\mathrm{B}$, from the bottom of the organic layer to $10 \mathrm{~cm}$ depth) sample were collected using a trowel near the location of the soil block. Collected soil blocks and soil samples were stored individually in plastic bags, transported on ice to the laboratory within 1 to 4 days, and stored at $4{ }^{\circ} \mathrm{C}$ until processing (up to three months) to avoid alteration of fine-root traits that can occur with freezing. A total of 73 sample sets were collected in this study ( 5 regions, 3 sites per regions, 5 soil blocks per site, but only 3 blocks could be collected at Nelson site N2).

To extract fine roots, each soil block was soaked in water overnight, and washed over a $4 \mathrm{~mm}$ screen. All fine-root branches (diameter $<2 \mathrm{~mm}$ ) and fragments $>3 \mathrm{~cm}$ in length were recovered from the sieve and sorted by tree species. To do this, we developed a morphological key from root samples of known species identity collected from our study sites (Figure S4). The proportion of roots belonging to other tree species was not estimated. Douglas-fir roots that were turgescent with visible, intact periderm and that had (if present) colorful, swollen ectomycorrhizal tips were considered live roots. For trait measurements, we selected intact root branches containing at least three root orders, live ectomycorrhizal tips, and minimal breakage. Whenever possible, selected branches were 
carefully cleaned with a soft brush and tweezers and analyzed immediately after extraction. Otherwise, branches were stored in a plastic bag with a damp paper towel (changed daily) at $4{ }^{\circ} \mathrm{C}$ for no more than 3 days until further analysis.

\subsection{Fine-Root Traits Measurements}

We selected five, live and intact Douglas-fir fine-root branches from each of 73 soil blocks. A total of 365 root branches were scanned on a desktop scanner (400 dpi, 165 level gray scale, EPSON Perfection V800 Photo, STD 4800) and analyzed with WinRHIZO pro 2016 software (Regent Instruments Inc., Quebec City, Canada). Branches were analyzed for topology (magnitude, altitude, and external path length). We acknowledge the possible limitations of scanning roots at 400 dpi for root length measurements, particularly for very fine roots [50]. However, in our study system, this resolution was a good trade-off between speed and accuracy, as we avoided scanning overlapping roots (i.e., root length density $<1 \mathrm{~cm} \mathrm{~cm}^{-2}$ ). Furthermore, our scans had a good contrast between the roots and the background as Douglas-fir is a relatively thick-rooted tree species (first-order root diameter $>0.40 \mathrm{~mm}$ ).

Following the initial scans of intact branches, each branch was divided into individual root orders using a scalpel under a stereomicroscope following the morphometric classification approach [51]. In our system, typical first-order roots were either comprised of ectomycorrhizal tips or displayed unbranched and uncolonized root tips. In all cases, we avoided thicker, longer pioneer roots [52]. Each root order group was scanned separately and analyzed for morphology (total length, total surface area, average diameter, and total volume). For the measure of root volume and area, we used the total value rather than the sum of values provided for each diameter class [53], because, in our study system, these two methods of estimation led to similar results $\left(R^{2}=0.99\right.$ for length and $R^{2}=0.97$ for volume; data not shown). Root orders were then stored in envelopes, dried at $65{ }^{\circ} \mathrm{C}$ for $48 \mathrm{~h}$, and weighed. For each root order group, SRL $\left(\mathrm{m} \mathrm{g}^{-1}\right)$ was calculated as the ratio of root length to root dry mass; SRA $\left(\mathrm{cm}^{2} \mathrm{~g}^{-1}\right)$ as the ratio of root surface area to dry mass; and RTD $\left(\mathrm{mg} \mathrm{cm}^{-3}\right)$ as the ratio of root dry mass to root volume. To determine C and N concentration (\%; Thermo Scientific Flash $2000 \mathrm{NC}$ analyzer) in each of the three root orders, we randomly selected samples for each of the 15 sites as follows. Two soil blocks were randomly selected out of five originally sampled per site, and two root branches were randomly selected out of five originally sampled per block for a total of 180 root samples. The number of first-order roots for each branch was determined with the ImageJ software (National Institute of Health, USA). Root branching intensity was calculated as the number of first-order roots per length of second-order roots. The dichotomous branching index was calculated as:

$$
\mathrm{DBI}=[\mathrm{Pe}-\min (\mathrm{Pe})] /[\max (\mathrm{Pe})-\min (\mathrm{Pe})],
$$

with Pe, the external path length, defined as the sum of the number of root segments from the most distal root segment to the most basal root segment (i.e., third-order roots).

\subsection{Climate and Soil Data}

We obtained long-term averages for climatic variables over the period 1981-2010 from ClimateNA (http://www.climatewna.com/; [54]). To obtain soil properties, organic and mineral soil samples were air-dried and sieved to $2 \mathrm{~mm}$. Samples were then sent to the analytical laboratory of the B.C. Ministry of Environment (Victoria, BC, Canada). Total soil C and N concentration (\%) were measured using a combustion elemental analyzer (Thermo Scientific Flash $2000 \mathrm{NC}$ analyzer). For available P. ( $\mathrm{PO}_{4}-\mathrm{P}$; orthophosphate as phosphorus), samples were prepared with the Bray P-1 method (dilute acid fluoride [55]) and analyzed with a UV/visible Spectrophotometer (Agilent Cary 60). To estimate the effective cation exchange capacity (CEC), cations were extracted from the soil samples with $0.1 \mathrm{Mbarium}$ chloride [56] and analyzed with an ICP-OES spectrometer (Teledyne Leeman, Prodigy Dual view). 


\subsection{Data Analyses}

Statistical analyses were conducted in $\mathrm{R}$ version 3.5.1 [57] and results were considered statistically significant at $p<0.05$. To test whether fine-root functional traits related to the environment at the intraspecific level, we fitted linear mixed-effects models (LMMs). For each root order we separately considered SRL, SRA, RTD, root diameter, and root C:N, as response variables. For the third-order root $\mathrm{C}: \mathrm{N}$ ratio, we used a linear model (multiple linear regression) instead, as the random effects were not significant. Models for branching intensity and DBI were fitted considering the whole absorptive root branch (as opposed to considering each root order separately). Before analyses, all response variables were $\log _{10}$-transformed to meet the assumptions of the LMMs. Data points that were $>3$ standard deviations from the region median were considered as statistical outliers and removed. This represented $<2 \%$ of the data points for each trait and did not change the outcome of the LMMs. Climate (i.e., MAT and MAP) and soil variables (i.e., C:N ratio, avail. P, CEC) were added as fixed factors, while region, site, and tree were added as nested random factors. We also added stand age, Douglas-fir basal area, soil type, and stand composition (mixed vs. pure) as fixed factors. However, to avoid over-parametrization and multicollinearity among predictors, these variables were removed from LMMs as they all had a variance inflation factor $>3$ [58]. To fit LMMs, we used the 'lmer' function from the package lme4 [59]. Global LMMs had this form:

$$
\log _{10}(\text { Fine-root trait }) \sim \mathrm{MAP}+\mathrm{MAT}+\mathrm{CEC}+\text { Soil C:N + Soil avail. P+ (1|region/site/tree). }
$$

We used the function 'step' from the lmerTest package to eliminate non-significant effects of LMMs based on the Akaike information criterion [60]. We checked LMMs adequacy with the 'plot_model' function from the sjPlot package [61] and LMMs fit using the conditional $\mathrm{R}^{2}$ (variance explained by the entire model, including both fixed and random effects) and marginal $\mathrm{R}^{2}$ (variance explained by the fixed effects) values, estimated following Nakagawa and Schielzeth [62]. We tested LMM significance with the log likelihood ratio and the significance of fixed effects with a type II Wald $\chi^{2}$ test. Standardized beta coefficients, and their 95\% confidence intervals were extracted with the 'beta.coef' function from the sjstats package. Pairwise trait relationships were assessed using Spearman's rank-order correlation because the assumption of pairwise linear relationships between variables of the Pearson product-moment correlation was violated. Trait coordination was explored using Principal Component Analysis (PCA). We acknowledge the mathematical dependence among root morphological traits and discuss the results accordingly. To quantify fine-root trait variation within sites, among sites, and across regions along the biogeographic gradient, we performed a variance partitioning analysis. For each root trait (i.e., SRL, SRA, RTD, root diameter, root C:N, Branching intensity, and DBI), we fitted linear models (ANOVA) with nested random effects in this order: region, site, tree. To partition variance among these hierarchically structured ecological scales, we used the function 'varcomp' from the package ape [60].

Supplementary Materials: The following are available online at http://www.mdpi.com/2223-7747/8/7/199/s1. Figure S1: Ordination plot and associated scores of samples across a biogeographic gradient based on principal component analysis of fine root traits of second-order and third-order roots of interior Douglas-fir. Figure S2: Distribution of branching intensity and dichotomous branching index values across a biogeographic gradient and variance partitioning of architectural traits at different hierarchically structured ecological scales. Figure S3: Ordination plot of study regions (five in total) across a biogeographic gradient based on principal component analysis of climatic, edaphic and site variables. Figure S4: Description of morphological attributes of fine roots for three coniferous tree species encountered in this study. Table S1: Means and standard error (SE) of fine-root morphological, chemical and architectural traits of interior Douglas-fir across a biogeographic gradient made of five study locations. Table S2: Spearman's correlation coefficient for pairwise root order (first three root orders) relationships. Table S3: Stand properties of the 15 study sites selected across a biogeographic gradient in Western Canada.

Author Contributions: Conceptualization, C.E.D., W.J.R. and S.W.S.; Data curation, C.E.D.; Formal analysis, C.E.D.; Funding acquisition, W.J.R. and S.W.S.; Investigation, C.E.D. and W.J.R.; Methodology, C.E.D., M.L.M., W.J.R., S.D.A.-D. and S.W.S.; Project administration, W.J.R. and S.W.S.; Resources, S.W.S.; Supervision, S.W.S.; 
Validation, M.L.M. and S.W.S.; Visualization, C.E.D.; Writing-original draft, C.E.D.; Writing-review \& editing, C.E.D., M.L.M., S.D.A.-D. and S.W.S.

Funding: This research was funded by the NATURAL SCIENCES AND ENGINEERING RESEARCH COUNCIL OF CANADA (NSERC).

Acknowledgments: We thank the British Columbia Ministry of Forests, Lands, and Natural Resource Operations for facilitating this research. We also thank to Robert D. Guy and Lori D. Daniels at the University of British Columbia. We thank Brian Pickles, Morgane Maillard and Katie McMahen for field and analytical assistance. Thanks to our undergraduate research assistants: Jaylen Bastos, Charles Cohen, Supreet Dhillon, Caitlin Low, Esmee MacDonald, Daniel Malvin, Hannah Sachs, Yifan Sun, Bailey Williams, Tong Ye, and Zuofang Zhang.

Conflicts of Interest: The authors declare no conflict of interest.

\section{References}

1. Laliberté, E. Below-ground frontiers in trait-based plant ecology. New Phytol. 2017, 213, 1597-1603. [CrossRef] [PubMed]

2. McCormack, M.L.; Guo, D.; Iversen, C.M.; Chen, W.; Eissenstat, D.M.; Fernandez, C.W.; Li, L.; Ma, C.; Ma, Z.; Poorter, H.; et al. Building a better foundation: Improving root-trait measurements to understand and model plant and ecosystem processes. New Phytol. 2017, 215, 27-37. [CrossRef] [PubMed]

3. Ostonen, I.; Truu, M.; Helmisaari, H.-S.; Lukac, M.; Borken, W.; Vanguelova, E.; Godbold, D.L.; Lõhmus, K.; Zang, U.; Tedersoo, L.; et al. Adaptive root foraging strategies along a boreal-temperate forest gradient. New Phytol. 2017, 215, 977-991. [CrossRef] [PubMed]

4. Ma, Z.; Guo, D.; Xu, X.; Lu, M.; Bardgett, R.D.; Eissenstat, D.M.; McCormack, M.L.; Hedin, L.O. Evolutionary history resolves global organization of root functional traits. Nature 2018, 555, 94-97. [CrossRef] [PubMed]

5. Kong, D.; Wang, J.; Wu, H.; Valverde-Barrantes, O.J.; Wang, R.; Zeng, H.; Kardol, P.; Zhang, H.; Feng, Y. Nonlinearity of root trait relationships and the root economics spectrum. Nat. Commun. 2019, 10, 2203. [CrossRef]

6. Freschet, G.T.; Valverde-Barrantes, O.J.; Tucker, C.M.; Craine, J.M.; McCormack, M.L.; Violle, C.; Fort, F.; Blackwood, C.B.; Urban-Mead, K.R.; Iversen, C.M.; et al. Climate, soil and plant functional types as drivers of global fine-root trait variation. J. Ecol. 2017, 105, 1182-1196. [CrossRef]

7. Li, H.; Liu, B.; McCormack, M.L.; Ma, Z.; Guo, D. Diverse belowground resource strategies underlie plant species coexistence and spatial distribution in three grasslands along a precipitation gradient. New Phytol. 2017, 216, 1140-1150. [CrossRef]

8. Simpson, A.H.; Richardson, S.J.; Laughlin, D.C. Soil-climate interactions explain variation in foliar, stem, root and reproductive traits across temperate forests: Soil-climate interactions explain functional trait variation. Glob. Ecol. Biogeogr. 2016, 25, 964-978. [CrossRef]

9. Valverde-Barrantes, O.J.; Freschet, G.T.; Roumet, C.; Blackwood, C.B. A worldview of root traits: The influence of ancestry, growth form, climate and mycorrhizal association on the functional trait variation of fine-root tissues in seed plants. New Phytol. 2017, 215, 1562-1573. [CrossRef]

10. McCormack, L.M.; Adams, T.S.; Smithwick, E.A.H.; Eissenstat, D.M. Predicting fine root lifespan from plant functional traits in temperate trees. New Phytol. 2012, 195, 823-831. [CrossRef]

11. Reich, P.B. The world-wide 'fast-slow' plant economics spectrum: A traits manifesto. J. Ecol. 2014, 102, 275-301. [CrossRef]

12. Roumet, C.; Birouste, M.; Picon-Cochard, C.; Ghestem, M.; Osman, N.; Vrignon-Brenas, S.; Cao, K.; Stokes, A. Root structure-function relationships in 74 species: Evidence of a root economics spectrum related to carbon economy. New Phytol. 2016, 210, 815-826. [CrossRef] [PubMed]

13. Weemstra, M.; Mommer, L.; Visser, E.J.W.; van Ruijven, J.; Kuyper, T.W.; Mohren, G.M.J.; Sterck, F.J. Towards a multidimensional root trait framework: A tree root review. New Phytol. 2016, 211, 1159-1169. [CrossRef] [PubMed]

14. Wang, R.; Wang, Q.; Zhao, N.; Xu, Z.; Zhu, X.; Jiao, C.; Yu, G.; He, N. Different phylogenetic and environmental controls of first-order root morphological and nutrient traits: Evidence of multidimensional root traits. Funct. Ecol. 2018, 32, 29-39. [CrossRef]

15. Erktan, A.; Roumet, C.; Bouchet, D.; Stokes, A.; Pailler, F.; Munoz, F. Two dimensions define the variation of fine root traits across plant communities under the joint influence of ecological succession and annual mowing. J. Ecol. 2018, 106, 2031-2042. [CrossRef] 
16. De la Riva, E.G.; Violle, C.; Pérez-Ramos, I.M.; Marañón, T.; Navarro-Fernández, C.M.; Olmo, M.; Villar, R. A Multidimensional Functional Trait Approach Reveals the Imprint of Environmental Stress in Mediterranean Woody Communities. Ecosystems 2018, 21, 248-262. [CrossRef]

17. Zhou, M.; Bai, W.; Zhang, Y.; Zhang, W.-H. Multi-dimensional patterns of variation in root traits among coexisting herbaceous species in temperate steppes. J. Ecol. 2018, 106, 2320-2331. [CrossRef]

18. McGill, B.J.; Enquist, B.J.; Weiher, E.; Westoby, M. Rebuilding community ecology from functional traits. Trends Ecol. Evol. 2006, 21, 178-185. [CrossRef]

19. Siefert, A.; Violle, C.; Chalmandrier, L.; Albert, C.H.; Taudiere, A.; Fajardo, A.; Aarssen, L.W.; Baraloto, C.; Carlucci, M.B.; Cianciaruso, M.V.; et al. A global meta-analysis of the relative extent of intraspecific trait variation in plant communities. Ecol. Lett. 2015, 18, 1406-1419. [CrossRef]

20. Fajardo, A.; Siefert, A. Intraspecific trait variation and the leaf economics spectrum across resource gradients and levels of organization. Ecology 2018, 99, 1024-1030. [CrossRef]

21. Zadworny, M.; McCormack, M.L.; Mucha, J.; Reich, P.B.; Oleksyn, J. Scots pine fine roots adjust along a 2000-km latitudinal climatic gradient. New Phytol. 2016, 212, 389-399. [CrossRef] [PubMed]

22. Zadworny, M.; McCormack, M.L.; Żytkowiak, R.; Karolewski, P.; Mucha, J.; Oleksyn, J. Patterns of structural and defense investments in fine roots of Scots pine (Pinus sylvestris L.) across a strong temperature and latitudinal gradient in Europe. Glob. Change Biol. 2017, 23, 1218-1231. [CrossRef] [PubMed]

23. Doi, R.; Tanikawa, T.; Miyatani, K.; Hirano, Y. Intraspecific variation in morphological traits of root branch orders in Chamaecyparis obtusa. Plant Soil 2017, 416, 503-513. [CrossRef]

24. Johnson, D.; Martin, F.; Cairney, J.W.G.; Anderson, I.C. The importance of individuals: Intraspecific diversity of mycorrhizal plants and fungi in ecosystems: Tansley review. New Phytol. 2012, 194, 614-628. [CrossRef] [PubMed]

25. Des Roches, S.; Post, D.M.; Turley, N.E.; Bailey, J.K.; Hendry, A.P.; Kinnison, M.T.; Schweitzer, J.A.; Palkovacs, E.P. The ecological importance of intraspecific variation. Nat. Ecol. Evol. 2018, 2, 57-64. [CrossRef] [PubMed]

26. Defrenne, C.E.; Philpott, T.J.; Guichon, S.H.A.; Roach, W.J.; Pickles, B.J.; Simard, S.W. Shifts in ectomycorrhizal fungal communities and exploration types relate to the environment and fine-root traits across interior Douglas-fir forests of western Canada. Front. Plant Sci. 2019, 10. [CrossRef]

27. Kong, D.; Ma, C.; Zhang, Q.; Li, L.; Chen, X.; Zeng, H.; Guo, D. Leading dimensions in absorptive root trait variation across 96 subtropical forest species. New Phytol. 2014, 203, 863-872. [CrossRef]

28. Liese, R.; Alings, K.; Meier, I.C. Root Branching Is a Leading Root Trait of the Plant Economics Spectrum in Temperate Trees. Front. Plant Sci. 2017, 8. [CrossRef]

29. Rehfeldt, G.E.; Leites, L.P.; Bradley St Clair, J.; Jaquish, B.C.; Sáenz-Romero, C.; López-Upton, J.; Joyce, D.G. Comparative genetic responses to climate in the varieties of Pinus ponderosa and Pseudotsuga menziesii: Clines in growth potential. For. Ecol. Manag. 2014, 324, 138-146. [CrossRef]

30. Šmilauerová, M.; Šmilauer, P. Morphological responses of plant roots to heterogeneity of soil resources. New Phytol. 2002, 154, 703-715. [CrossRef]

31. Beidler, K.V.; Taylor, B.N.; Strand, A.E.; Cooper, E.R.; Schönholz, M.; Pritchard, S.G. Changes in root architecture under elevated concentrations of $\mathrm{CO}_{2}$ and nitrogen reflect alternate soil exploration strategies. New Phytol. 2015, 205, 1153-1163. [CrossRef] [PubMed]

32. Kramer-Walter, K.R.; Bellingham, P.J.; Millar, T.R.; Smissen, R.D.; Richardson, S.J.; Laughlin, D.C. Root traits are multidimensional: Specific root length is independent from root tissue density and the plant economic spectrum. J. Ecol. 2016, 104, 1299-1310. [CrossRef]

33. Liu, B.; Li, H.; Zhu, B.; Koide, R.T.; Eissenstat, D.M.; Guo, D. Complementarity in nutrient foraging strategies of absorptive fine roots and arbuscular mycorrhizal fungi across 14 coexisting subtropical tree species. New Phytol. 2015, 208, 125-136. [CrossRef] [PubMed]

34. McCormack, M.L.; Iversen, C.M. Physical and functional constraints on viable belowground acquisition strategies. 2019; Submitted.

35. Beiler, K.J.; Durall, D.M.; Simard, S.W.; Maxwell, S.A.; Kretzer, A.M. Architecture of the wood-wide web: Rhizopogon spp. genets link multiple Douglas-fir cohorts. New Phytol. 2010, 185, 543-553. [CrossRef] [PubMed] 
36. Barker, J.S.; Simard, S.W.; Jones, M.D.; Durall, D.M. Ectomycorrhizal fungal community assembly on regenerating Douglas-fir after wildfire and clearcut harvesting. Oecologia 2013, 172, 1179-1189. [CrossRef] [PubMed]

37. Eissenstat, D.M.; Kucharski, J.M.; Zadworny, M.; Adams, T.S.; Koide, R.T. Linking root traits to nutrient foraging in arbuscular mycorrhizal trees in a temperate forest. New Phytol. 2015, 208, 114-124. [CrossRef] [PubMed]

38. Cheng, L.; Chen, W.; Adams, T.S.; Wei, X.; Li, L.; McCormack, M.L.; DeForest, J.L.; Koide, R.T.; Eissenstat, D.M. Mycorrhizal fungi and roots are complementary in foraging within nutrient patches. Ecology 2016, 97, 2815-2823. [CrossRef]

39. Twieg, B.D.; Durall, D.M.; Simard, S.W. Ectomycorrhizal fungal succession in mixed temperate forests. New Phytol. 2007, 176, 437-447. [CrossRef]

40. Agerer, R. Fungal relationships and structural identity of their ectomycorrhizae. Mycol. Prog. 2006, 5, 67-107. [CrossRef]

41. Tobner, C.M.; Paquette, A.; Messier, C. Interspecific coordination and intraspecific plasticity of fine root traits in North American temperate tree species. Front. Plant Sci. 2013, 4. [CrossRef]

42. Messier, J.; Lechowicz, M.J.; McGill, B.J.; Violle, C.; Enquist, B.J. Interspecific integration of trait dimensions at local scales: The plant phenotype as an integrated network. J. Ecol. 2017, 105, 1775-1790. [CrossRef]

43. Trocha, L.K.; Mucha, J.; Eissenstat, D.M.; Reich, P.B.; Oleksyn, J. Ectomycorrhizal identity determines respiration and concentrations of nitrogen and non-structural carbohydrates in root tips: A test using Pinus sylvestris and Quercus robur saplings. Tree Physiol. 2010, 30, 648-654. [CrossRef] [PubMed]

44. Pickles, B.J.; Genney, D.R.; Potts, J.M.; Lennon, J.J.; Anderson, I.C.; Alexander, I.J. Spatial and temporal ecology of Scots pine ectomycorrhizas. New Phytol. 2010, 186, 755-768. [CrossRef] [PubMed]

45. Aitken, S.N.; Yeaman, S.; Holliday, J.A.; Wang, T.; Curtis-McLane, S. Adaptation, migration or extirpation: Climate change outcomes for tree populations: Climate change outcomes for tree populations. Evol. Appl. 2008, 1, 95-111. [CrossRef] [PubMed]

46. Pickles, B.J.; Gorzelak, M.A.; Green, D.S.; Egger, K.N.; Massicotte, H.B. Host and habitat filtering in seedling root-associated fungal communities: Taxonomic and functional diversity are altered in 'novel' soils. Mycorrhiza 2015, 25, 517-531. [CrossRef] [PubMed]

47. Meidinger, D.V.; Pojar, J. Ecosystems of British Columbia; Research Branch, Ministry of Forests: Victoria, BC, Canada, 1991; ISBN 978-0-7718-8997-4.

48. Soil Classification Working Group. The Canadian System of Soil Classification; 3rd (revised); Agriculture and Agri-Food Canada Publication 1646: Ottawa, Canada, 1998.

49. BC Ministry of Forests and Range. Field manual for describing terrestrial ecosystems; B.C. Ministry of Forests and Range: Victoria, Canada, 2010; ISBN 978-0-7726-6356-6.

50. Delory, B.M.; Weidlich, E.W.A.; Meder, L.; Lütje, A.; van Duijnen, R.; Weidlich, R.; Temperton, V.M. Accuracy and bias of methods used for root length measurements in functional root research. Methods Ecol. Evol. 2017, 8, 1594-1606. [CrossRef]

51. Pregitzer, K.S.; Deforest, J.L.; Burton, A.J.; Allen, M.F.; Ruess, R.W.; Hendrick, R.L. FINE ROOT ARCHITECTURE OF NINE NORTH AMERICAN TREES. Ecol. Monogr. 2002, 72, 17. [CrossRef]

52. Zadworny, M.; Eissenstat, D.M. Contrasting the morphology, anatomy and fungal colonization of new pioneer and fibrous roots. New Phytol. 2011, 190, 213-221. [CrossRef]

53. Rose, L. Pitfalls in Root Trait Calculations: How Ignoring Diameter Heterogeneity Can Lead to Overestimation of Functional Traits. Front. Plant Sci. 2017, 8. [CrossRef]

54. Wang, T.; Hamann, A.; Spittlehouse, D.; Carroll, C. Locally Downscaled and Spatially Customizable Climate Data for Historical and Future Periods for North America. PLOS ONE 2016, 11, e0156720. [CrossRef]

55. Kalra, Y.; Maynard, D. Methods Manual for Forest Soil and Plant Analysis; nformation Report NOR-X-319; Forestry Canada, Northwest region, Northern Forestry Center: Edmonton, AB, Canada, 1991; Available online: http://cfs.nrcan.gc.ca/pubwarehouse/pdfs/11845.pdf (accessed on May 12019 ).

56. Hendershot, W.H.; Duquette, M. A Simple Barium Chloride Method for Determining Cation Exchange Capacity and Exchangeable Cations1. Soil Sci. Soc. Am. J. 1986, 50, 605. [CrossRef]

57. R Core Team. A Language and Environment For Statistical Computing; R Foundation for Statistical Computing: Vienna, Austria, 2018. 
58. Zuur, A.F.; Ieno, E.N.; Elphick, C.S. A protocol for data exploration to avoid common statistical problems. Methods Ecol. Evol. 2010, 1, 3-14. [CrossRef]

59. Bates, D.; Maechler, M.; Bolker, B.; Walker, S.; Christensen, R.H.B.; Singmann, H.; Dai, B.; Scheipl, F.; Grothendieck, G.; Green, P.; et al. Ime4: Linear Mixed-Effects Models using "Eigen" and S4. 2018. Available online: https://cran.r-project.org/web/packages/lme4/index.html (accessed on May 12019 ).

60. Venables, W.N.; Ripley, B.D. Modern Applied Statistics with S.; Statistics and Computing, 4th ed.; Springer: New York, NY, USA, 2002; ISBN 978-0-387-95457-8.

61. Lüdecke, D. sjPlot: Data Visualization for Statistics in Social Science. 2019; Available online: http: //cran.r-project.org/package=sjPlot (accessed on 29 June 2019).

62. Nakagawa, S.; Schielzeth, H. A general and simple method for obtaining $R^{2}$ from generalized linear mixed-effects models. Methods Ecol. Evol. 2013, 4, 133-142. [CrossRef]

(C) 2019 by the authors. Licensee MDPI, Basel, Switzerland. This article is an open access article distributed under the terms and conditions of the Creative Commons Attribution (CC BY) license (http://creativecommons.org/licenses/by/4.0/). 